\title{
Education Through Athletics: An Examination of Academic Courses Designed for NCAA Athletes
}

\author{
Erianne A. Weight \\ University of North Carolina at Chapel Hill \\ Matt R. Huml \\ Texas Tech University
}

\begin{abstract}
Fundamental to the union of athletics and the academy is an underlying theoretical premise of education through athletics. Despite an organizational union of varsity athletics and American higher education, athletics is commonly viewed as extracurricular, tangential, or a detractor from the educational mission of the academy, and athletics-centric curricula have historically not been viewed as worthy of academic credit despite documented educational benefits. Through survey of a stratifiedrandom sample of National Collegiate Athletics Association (NCAA) Division I, II, and III athletic academic advisors $(n=240)$, this exploratory study examined the prevalence, design, and institutional perceptions of classes offered exclusively for varsity athletes. Results indicate roughly $1 / 3$ of sample schools facilitate athletecentric academic opportunities, with the majority of courses being 1 st semester transition, physical education, or leadership courses. Academic opportunities for athletes were greatest in western, public, and Division I institutions.
\end{abstract}

Keywords: education through athletics, athletics in the academy, credit for sport participation, intercollegiate athletics reform, college sport reform

Fundamental to the union of athletics and the academy is an underlying theoretical premise of education through athletics (Bowen \& Levin, 2003; Brand, 2006; Weight, Cooper, \& Popp, 2015). In an era of heightened scrutiny where the governance structure of American intercollegiate athletics is being questioned in the courtroom and throughout headlines, it is critical to understand the organizational and philosophical structures that support this system. As this manuscript comes to print, the political-educational arena is particularly charged in higher education as governmental scrutiny and control is increasing while funding and support is decreasing (Cullingford \& Blewitt, 2013). Simultaneously, the landscape of

Weight is with Sport Administration, University of North Carolina at Chapel Hill, Chapel Hill, North Carolina. Huml is with the Dept. of Kinesiology \& Sport Management, Texas Tech University, Lubbock, Texas. Address author correspondence to Erianne Weight at eweight@unc.edu. 
intercollegiate athletics is being challenged, as headlines and lawsuits are calling for broad-sweeping reform due to excessive commercialism (Gerdy, 2006; Ross, 2012; Smith 2011), unprincipled behavior (Smith \& Willingham, 2015), athletic primacy (Fountain \& Finley, 2011; Hardin \& Pate, 2013; Huml, Hancock \& Bergman, 2014; Wolverton, 2014); and athlete exploitation (McCormick \& McCormick, 2006; Sack \& Staurowsky, 1998; Southall \& Staurowsky, 2013; VanRheenen, 2013).

Building on the literature addressing these pressing issues, the focus of this inquiry is on the academic integration of athletics within the American academy. If there is an inherent educational value in varsity athletics, is this education worthy of academic credit? How integrated is this educational endeavor within the academic fabric of the university? This study addresses these important questions in the literature and industry dialogue surrounding the unique positioning of intercollegiate athletics by providing insight into the institutional practices of facilitating academic courses designed specifically for varsity athletes within NCAA Division I, II, and III institutions.

To understand the present phenomenon of sport within the university, it is necessary to understand its historical development. Intercollegiate athletics was born out of a unique historical moment in American history wherein physical activity was embraced as a vehicle to character development (Putney, 2009). Faculty, administrators, and politicians in the late 1800s and early 1900s embraced a new model of sanctioned varsity athletics in the United States distinct from the athletics systems in the rest of the world (Ingrassia, 2012, Rader, 1999). Progressives in this movement believed the integration of football into the academy would foster towngown relations in an era of "ivory tower" public-faculty dissonance, and provide an avenue to facilitate publicity for the university (Ingrassia, 2012; Oriard, 2012). Complementary to these corporate motives was the popular notion that competitive sports and physical education facilitated development of the ideal Christian person (Hughes, 1968; Park, 2007; Putney, 2009). Competitive sport within the academy, then, would attract and build disciplined college students who were physically and intellectually strong, tough, and dedicated to serving others (Ingrassia, 2012; Putney, 2009). These parallel initiatives reinforced the male-dominated emphasis within sport, further strengthening the traditional patriarchy established in American society (Beyer \& Hannah, 2000).

Though the legitimacy of the sport-for-development premise has been a topic of debate since the integration of varsity athletics within higher education (Desrochers, 2013; Ingrassia, 2012; Oriard, 2001; Smith, 2011; Thelin, 1994), the notion of education through athletics is maintained within official institutional policy, statements of vision, marketing efforts, and financial streams (Cooper, Weight, \& Pierce, 2014; Huml, Svensson, \& Hancock, 2014; NCAA, 2015; Southall et.al., 2011). Despite this clear union of athletics within the business enterprise of higher education in the United States, the integration of athletics within the academy is often lacking (Brand, 2006; Weight et al., 2015), as athletics is commonly viewed as "other," "extracurricular, or even a "detractor" from the educational mission of the academy (Benford, 2007; Gerdy, 2006; Zimbalist, 1999). As such, educational stakeholders may often echo the questions raised by Murdoch (1990): "What is the place of sport in education?" and "What is the role of education in sport?" (p. 67).

Specific educational and life-skill benefits of participation in intercollegiate athletics have been documented, yet athletics-centric curricula have historically not 
been viewed as worthy of academic credit within American higher education beyond the subdiscipline level (e.g., sport management, history, economics, or sociology) (Brand, 2006; Colas, 2015; Jenkins, 2011; Weight, 2015). There are, however, emerging accounts of programs wherein athletic participation and its education/ life-skill benefits have been integrated into "traditional" curricula (Adeniji, 2015; Clubb, 2012), though the prevalence of these programs is unknown. This study will address this critical gap in the literature and provide a foundation for future research and theory development on education through athletics within higher education by exploring the prevalence, content, and perceptions of athlete-centric courses within NCAA institutions.

\section{Conceptual Rationale}

\section{Educational Effects of Participation in Intercollegiate Athletics}

Building upon the traditionally accepted notions of the "character-building" benefits that can be derived from participation in sport (Gould \& Carson, 2008; Hellison, 2003; Putney, 2009), there is a growing body of literature quantifying the specific educational effects of college sport participation. Participation in intercollegiate athletics has been associated with increased educational engagement (Umbach, Palmer, Kuh, \& Hannah, 2006), satisfaction with the overall college experience (Astin, 1993; Gill, 2015; Paule-Koba \& Farr, 2013; Pascarella \& Smart, 1991; Plunkett, Weight, Osborne, \& Lancaster, 2016), positional leadership (Anderson, 2012), motivation to earn a college degree (Astin, 1993; Pascarella \& Smart, 1991), and higher graduation rates (Corack, 2014; Long \& Caudill, 1991). These studies used samples including a broad array of sports and athletes in NCAA Division I/ II/III and NAIA institutions (Anderson, 2012: $n=1,498$; Astin, 1993: $n=24,847$; Pascarella \& Smart, 1991: $n=290$ black and $n=1,716$ white men; Umbach et al., 2006: $n=49,407$ ), in addition to more focused samples including nonrevenue athletes from Division I (Plunkett et al., 2016: $n=120$ ) and Division I and III (Paule-Koba \& Farr, 2013: $n=229$ ), with one study concentrating on community college student-athletes (Gill, 2015: $n=14$ ).

While these studies have provided a foundation of data documenting the positive educational benefits of participation in intercollegiate athletics, they have been contradicted by other research which demonstrates participation in intercollegiate athletics can have a negative association with satisfaction and involvement in the college experience when data are disaggregated by gender and sport-with particularly dramatic differences between Division I "revenue generating" football and basketball black male athletes and traditional students (Fountain \& Finley, 2011; Lanter \& Hawkins, 2013; Pascarella, Truckenmiller, Nora, Terenzini, Edison, \& Hagedorn, 1999; Van Rheenen, 2011; 2013). Scholars have raised concerns about the academic readiness of Division I athletes (Eckard, 2010; Lawrence, Harrison, \& Stone, 2009), and an institutional culture of faculty attitudes (Benson, 2000; Comeaux \& Harrison, 2007; Cooper \& Hawkins, 2014), eligibility-focused academic advisors (Fountain \& Finley, 2009), and peer-stereotyping (Benson, 2000) within an administrator-driven "system of practices that discourage[s] student involvement with academics" (Benson, 2000, p. 239; Donnor, 2005). These 
concerns are supported by publicized data of graduation and retention rates within this demographic being below other athletes and the general student population when factoring out transfer student data (College Sport Research Institute, 2015; Comeaux \& Harrison, 2007; National Collegiate Athletic Association, n.d.). As such, it is important to interpret these studies through an informed lens, as there is compelling evidence supporting the notion that the collegiate athlete experience has tremendous variance between demographic subgroups.

Building on studies of educational experiences, The Center for Learning Outcomes Assessment (2010) conducted a University Learning Outcomes Assessment (UniLOA) for the demographic of varsity athletes designed to measure growth in seven areas considered indicative of future success by employers, academicians, managers, and researchers. These points of measure included critical thinking, self-awareness, communication, diversity, citizenship, relationship, and leadership. The purpose of the UniLOA was to measure general college student growth, learning, and development beyond academics. Results of the athlete-study revealed that, by a student's final semester, athletes $(n=1,574)$ performed at a higher level in almost every area than their nonathlete counterparts when compared with the UNILOA National Database sample $(n=18,257)$ (Center for Learning Outcomes Assessment, 2010). While both male and female athletes reported significantly lower levels of behaviors measured by the UniLOA when they enter college, their overall rate of growth, learning, and development was superior to nonathlete students throughout their college careers (UniLOA, 2011). These athlete responses included NCAA Division I/II/III and NAIA institutions and represented almost all NCAA sanctioned sports, in addition to a similar gender and race breakdown as provided by the NCAA of the current student-athlete population (UniLOA, 2011; National Collegiate Athletic Association, 2015).

In an era where educational success is increasingly measured by job-placement (Bok, 2009; Mingle, 2000; Slaughter \& Rhoades, 2004), the occupational marketability of athletes is a foundational area of interest in the exploration of athletics as an integral part of the educational experience. Building on literature suggesting increased occupational marketability of intercollegiate athletes, (Long \& Caudill, 1991; McCann, 2012; Rosche, 2013; Williams, 2013) and industry movements such as the formation of companies aimed at connecting former collegiate athletes with employers who seek them (Soshnick, 2013). Chalfin et al. (2015) examined a sample of employers $(n=50)$ actively recruiting athletes to understand why they prefer to hire athletes over nonathletes. Employers associated a host of positive attributes with athletic participation, including competitive nature, goal-orientation, ability to handle pressure, strong work ethic, confidence, ability to embrace feedback, self-motivation, and ability to work with others. The perceived value of athletic participation was impacted by athletic success and leadership experiences, with no significant differences between sport, competition level (DI, II, or III), and gender (Chalfin et al., 2015).

Many of the findings in the Chalfin et al. (2015) study support previous literature documenting enhanced personal self-concept (Chickering \& Reisser, 1993; GastonGayles \& Hu, 2009), cognitive development (Chaddock, Neider, Voss, Gaspar, \& Kramer, 2011), higher wages of athletes over nonathletes (Henderson, Olbrecht, \& Polachek, 2006; Shulman \& Bowen, 2001), and a host of skills directly relevant to success in life after athletics (Center for Learning Outcomes Assessment, 2010; 
Henderson et al., 2006; Weight, Navarro, Huffman, \& Smith-Ryan, 2014; Williams, 2013). While the Chalfin et al. (2015) study targeted employers, the majority of studies above used broad samples of athletes from Division I, II, III, and NAIA schools (Center for Learning Outcomes Assessment, 2010: $n=1,574$; Henderson et al., 2006: $n=646$ ). Other samples included elite Ivy League (Shulman \& Bowen, 2001), and Division I institutions (Chaddock et al., 2001: $n=18$; Gaston-Gayles \& Hu, 2009: $n=410$; Weight et al., 2014: $n=435$ ).

Despite these measured educational outcomes and the broad financial and media integration of athletics within the academy, the pursuit of education through intercollegiate athletics has remained separate from the traditional academic structure of the American university (Brand, 2006; Weight et al., 2015), and there is little literature examining this strange cultural phenomenon. Athletics is largely viewed as "extra-curricular" and unworthy of academic credit whereas other disciplines with similar structures (e.g., dance, theater, and music) are viewed as "academic" and offered as degree programs worthy of academic credit at many institutions. Building an avenue to recognize and enrich the educational experiences through athletics may allow universities to expand their educational "footprint" and further achieve their organizational mission (Checkoway, 2001).

\section{Curricular Development and the Study of Sport}

The decisions about what a society should teach their children is a vexing quandary at the root of many political debates affecting curricular decisions and educational governance structures (Glatthorn \& Jailall, 2000; Marsh, 2009; Walker, 2002). Walker (2002) describes the dilemma in the ever-dynamic American society where the curriculum problem is especially difficult. "As the social fabric is stretched and ripped by change, innovators call for a new curriculum to prepare children for the New World while traditionalists call for repair and restoration. Who are we? Who do we want our children to be? What kind of world shall we prepare our children for?" (p. xiii). The evolution of what fields of study qualify as essential to education have been compared with multiple streams flowing through the system "ebbing at times, then gathering strength and flowing together in a dynamic confluence" (Glatthorn \& Jailall, 2000, p. 98).

Addressing the political realities of intercollegiate athletics and higher education reviewed above, one approach to strengthening the educational experiences of athletes is to formalize elite sport performance as an academic field of study. The legitimization and formalization of educational experiences that are already transpiring on the court, on the field, or on the track is one avenue to bridge the divide between academics and athletics (Brand, 2006; Colas, 2015; Feezell, 2015; Jenkins, 2011; Pargman, 2012; Weight, 2015).

Myles Brand, NCAA president from 2002 to 2009, delineated this approach to philosophical reform. A vocal proponent of the educational value of intercollegiate athletic participation and an "integrated view" of athletics within academia, he believed the importance of intercollegiate athletics was significantly undervalued. He condemned the academy for its bias against bodily skills, nonart, and its view on athletics as an auxiliary to the university unworthy of subsidy (Brand, 2006; Weight et al., 2015). Building upon this idea, Washington Post columnist Sally Jenkins posed the question "Why shouldn't we let kids major in sport?" Addressing 
this question, she argued, "high-performance athletes study a craft, with a science, theory, history and literature, just like music or dance or film majors do. Varsity athletes deserve significant academic credits for their incredibly long hours of training and practice, and if they fulfill a core curriculum they deserve degrees, too" (Jenkins, 2011, para 2).

Critics of this approach document academic-fraud (Smith \& Willingham, 2015), and academic clustering (Fountain \& Finley, 2009) associated with "bigtime" Division I intercollegiate athletics, and believe that merging athletic and academic interests would lead to additional corruption of the athlete academic experience. Others cite negatives associated with sport academies predominantly in Europe and Asia wherein promising young athletes are channeled into Olympic training programs. China has the highest level of participants with over 3,000 sport schools housing over 50,000 professional child athletes (Hong, 2004). These academies are often separate from traditional educational pathways and can lead to burnout, overuse injuries, pressure-to-perform related stress, and doping, leaving injured athletes or those who do not have professional prospects feeling abandoned and hopeless because of their early specialization in the sport niche (Capranica \& Millard-Stafford, 2011; Hong, 2004; Lang, 2010; Malina, 2010). A more moderate approach has been suggested utilizing educational enhancements through life-skills developmental programs, leadership training programs specific for athletes, or integrated academic-athletic experiential learning opportunities (Clubb, 2012; Hardcastle, Tye, Glassey, \& Hagger, 2015; Weight, 2015; Weight et al., 2015). Thus, there are several potential approaches toward the development of athletics as education: 1) Facilitate credit for participation in athletics that might fulfill university physical education requirements, 2) Develop athlete-centric courses that allow athletes to build upon the experiences they are having (e.g., sport psychology, nutrition, or leadership), or 3) Develop robust majors and/or minors that are sport-centric (e.g., football) or experience-centric (e.g., elite performance) that integrate the first two educational avenues mentioned in addition to additional science, theory, history and related literature. While the curricular debate ensues, we pursued this study to gather a baseline of data relative to the prevalence, content, and perceptions of educational courses (approach one or two) designed specifically for NCAA Division I, II, and III varsity athletes to provide a foundation for future research and theory development.

\section{Significance of this Study}

Despite a current lack of cultural legitimacy and institutional support for education through varsity athletics as a discipline worthy of academic credit in the United States (Colas, 2015; Jenkins, 2011; Weight, 2015), there is a conceptual rationale for the academic integration of athletics within the academy. Building upon the sport for development and educational effects of participation in intercollegiate athletics literature, there is literary support for curriculum development and the legitimate study of athletics within the academy (Brand, 2006; Weight et al., 2015). As a first step in developing this pedagogical pathway, the current study examined the prevalence and design of classes offered exclusively for varsity athletes at NCAA institutions to understand current practices and develop the groundwork 
for further research exploring athletics-centric curricula and education through athletics. Toward this end, specific research questions were developed.

[RQ1] What is the prevalence of academic courses designed for varsity athletes within NCAA institutions?

[RQ2] What is the curricular content of academic courses designed for varsity athletes within NCAA institutions?

[RQ3] What are the perceptions of academic advisors for athletes about academic courses designed for varsity athletes within NCAA institutions?

[RQ4] Does prevalence, content, or perceptions of athlete-centric courses differ based on NCAA division, public/private designation, institutional geographic location, or departmental values?

[RQ5] What is the institutional rationale for offering (or not offering) athletecentric courses?

\section{Method}

\section{Participants}

The population of interest in this study was athletic academic advisors within NCAA Divisions I, II, and III. Athletic academic advisors were chosen because of their familiarity with athletic and academic issues faced by varsity athletes. The survey participants were chosen using a random, stratified sampling technique. Stratified random sampling increases the likelihood of accomplishing a sample more representative of the population compared with random sample and requires and can help mitigate bias within the sample (DeVellis, 2012). Institutions were chosen from the NCAA webpage (i.e., http://www.ncaa.com/schools/a) and were stratified by division. A total of 600 universities were chosen ( 200 from each division). Academic advisors were then identified and contact information gathered by visiting each university's staff directory on the athletic department website. Individuals were included as eligible for the study only if they held titles directly related to academic services (e.g., advisor, academic counselor, or academic support specialist). Some institutions were later removed from the sample population after discovering the lack of specific academic support within their athletic department (this was more prevalent for smaller institutions or schools within the NCAA Division III model). This technique was chosen to identify academic advisors who oversee at least one sport and specialize in athlete development, which was verified in the invitation e-mail.

\section{Instrument}

Due to the specific exploratory nature of the research, it was necessary to develop an instrument. The researchers followed a number of steps to enhance its validity (Hopkins, 1998). First, the researchers examined literature on the athlete academic experience and developed questions that emerged through the literature review. Following the initial construction of the survey, a team of nine experts was consulted 
with expertise in educational inquiry methodology and survey construction (1), athletic academic advising (3), athlete-centric education (1), and research related to the athlete academic experience (4). The experts submitted suggestions for refinement of instrument verbiage for clarity in addition to suggestions about questions to add or remove to enhance the validity of the survey. Following expert-review, the instrument was piloted with a convenience sample of five athletic-academic administrators. Based upon feedback from this second round of external review, the researchers added one additional demographic measure. This process of examining of the literature, utilizing a panel of experts, and completing an instrument pilot with practitioners reinforces the content validity of the instrument (Cresswell, 2013).

Fourteen instrument items examined the existence and features of exclusive courses for athletes, with topics including course title and credits awarded for the course, whether the course was mandatory for athletes, the presence of an instructor and/or syllabus, history and/or reasoning for the course's offering, or current discussions on offering such a course. Each of the questions was either "yes/ no," multiple-choice, or open-ended. Demographic items included gender, race, NCAA division affiliation, public/private designation of institution, number of years working in intercollegiate athletics, and department values. The total number of items requiring responses from the participant varied based on responses. For example, if a participant responded "no" to whether their institution offered a course exclusively for athletes, the instrument automatically bypassed any items inquiring about the course's details. A specific sequence of responses could lead a participant to only answering ten items total: six content-specific questions and four demographic questions. Because the survey consisted of gathering qualitative perceptions, demographics, and institutional data, measures of reliability were limited to qualitative analysis methods.

\section{Procedure}

The instrument was disseminated to 1,062 participants using Qualtrics online survey program. Two weeks after the initial survey was disseminated, nonrespondents were sent a reminder. Two weeks after the reminder e-mail, the survey was closed. Quantitative data were analyzed utilizing Statistical Package for Social Sciences (SPSS). Data analysis included basic descriptive analysis to provide a framework of the wide array of respondents that are represented. In addition, chisquare tests were run to determine whether significant differences existed within any of the independent variables (NCAA division, public/private designation, and geographic location).

Qualitative data from two open-ended questions were organized independently by two researchers utilizing open in-vivo manual coding methods (Strauss \& Corbin, 1998). Emergent themes were compared and linked together through axial coding and the researchers then reviewed each response and independently coded the narratives utilizing the finalized code (Strauss \& Corbin, 1998). This two-cycle coding allowed each of the researchers to interpret the participant responses independently (Saldaña, 2009). Intercoder reliability was high for both coded narratives indicating a clear and reliable code as well as evidence for narrative validity with a Krippendorf's Alpha of 0.935 , and $94.5 \%$ agreement among coders within the narratives 
supporting athlete-specific courses $(n=73)$, and $94.4 \%$ agreement among coders within the narratives not supporting athlete-specific courses $(\alpha=.908, n=108)$ (Hayes \& Krippendorff, 2007).

\section{Results}

\section{Sample}

Of the 1,062 academic advisors invited to participate in the study, 240 participants completed the instrument, yielding a response rate of $22.6 \%$, an acceptable response rate given the method of data collection utilizing liberal conditions (Nulty, 2008). The sample was fairly representative of the population of NCAA academic advisors. Sixty-three percent of the respondents were female, coming within three percentage points of the overall academic-advisor gender distribution within NCAA institutions (NCAA, 2014). Representation from each NCAA subdivision was also very representative of the population with each subdivision within four percentage points of the actual population split (NCAA, 2014): $36.3 \%$ of respondents were from Division III institutions, 26.3\% from Division II, and 37.6\% from Division I institutions (see subdivision breakdown within Table 1). There was, however, overrepresentation of white respondents, with a $14 \%$ difference in the sample of white respondents (86\%), and the population of white NCAA academic advisor/counselors (72\%) according to the NCAA race and gender demographic database (Irick, 2015). Demographic characteristics of participants are listed in Table 1.

\section{Table 1 Demographic Characteristics of Participants ( $N=\mathbf{2 4 0})$}

\begin{tabular}{llcc}
\hline Characteristic & & $\boldsymbol{n}$ & $\%$ \\
\hline Gender & Female & 146 & 63.2 \\
& Male & 85 & 36.8 \\
Race/Ethnicity & & & \\
& White & 191 & 86.0 \\
& Non-White & 31 & 14.0 \\
NCAA Divisional Level & & & \\
& Division I-FBS & 23 & 9.6 \\
& Division I-FCS & 40 & 16.7 \\
& Division I-NF & 27 & 11.3 \\
& Division II & 63 & 26.3 \\
& Division III & 87 & 36.3 \\
& & & \\
& Public & 109 & 45.4 \\
& Private & 131 & 54.6 \\
\hline
\end{tabular}




\section{Prevalence of Athlete-Centric Courses [RQ 1, 2, \& 4]}

To differentiate credit opportunities for students, respondents were asked about two types of athlete-centric for-credit courses: courses for sport participation and traditional academic courses designed for athletes (e.g., sport psychology for varsity athletes). Responses from an initial question exploring the prevalence of athletics-centric courses revealed credit given for athletic participation, generally fulfilling a physical education requirement, at $33.9 \%$ of the respondent's institutions, and other academic courses designed specifically for athletes at $20.1 \%$ of the institutions (see Table 2).

When tested for variance in population subgroups, several significant differences emerged. Universities in the west were significantly more likely to grant academic credit for participation with $65.8 \%$ of western schools offering credit compared with $36.4 \%$ in the Midwest, $25.3 \%$ in the Northeast, and $17.8 \%$ in the Southeast $\chi^{2}(3, n=205)=25.28, p<.001$. Significant differences were also found between institutional subgroups in the prevalence of academic courses designed specifically for athletes. Division I institutions were significantly more likely to offer courses than their Division II or III counterparts $\chi^{2}(4, n=205)=24$. $14, p<$ .001. Similarly, public institutions were more likely to offer athlete-centric courses than private institutions $\chi^{2}(1, n=205)=5.471, p=.019$. No significant differences emerged based on stated athletic department values (see Table 3 ).

\section{Perceptions About Whether Athlete-Centric Courses Should Be Offered [RQ 3 \& 4]}

When respondents were asked whether they felt credit should be extended for sport participation, nearly half (49.3\%) believed that it should, while only $28.3 \%$ believed there should be unique academic courses designed for athletes. Differences also

\section{Table 2 Responses to Student-Athlete Credit Hour Opportunities}

\begin{tabular}{lcc}
\hline Response & $\mathbf{n}$ & $\%$ \\
\hline Can athletes receive credit for athletic participation? & & \\
Yes & 81 & 33.9 \\
No & 158 & 66.1 \\
Are there courses offered specifically for athletes? & & \\
Yes & 44 & 20.1 \\
No & 175 & 79.9 \\
Should Athletes Receive Credit for Participation? & & \\
Yes & 103 & 49.3 \\
No & 106 & 50.7 \\
Should There be Courses Explicitly for Athletes? & & \\
Yes & 58 & 28.3 \\
No & 147 & 71.7 \\
\hline
\end{tabular}




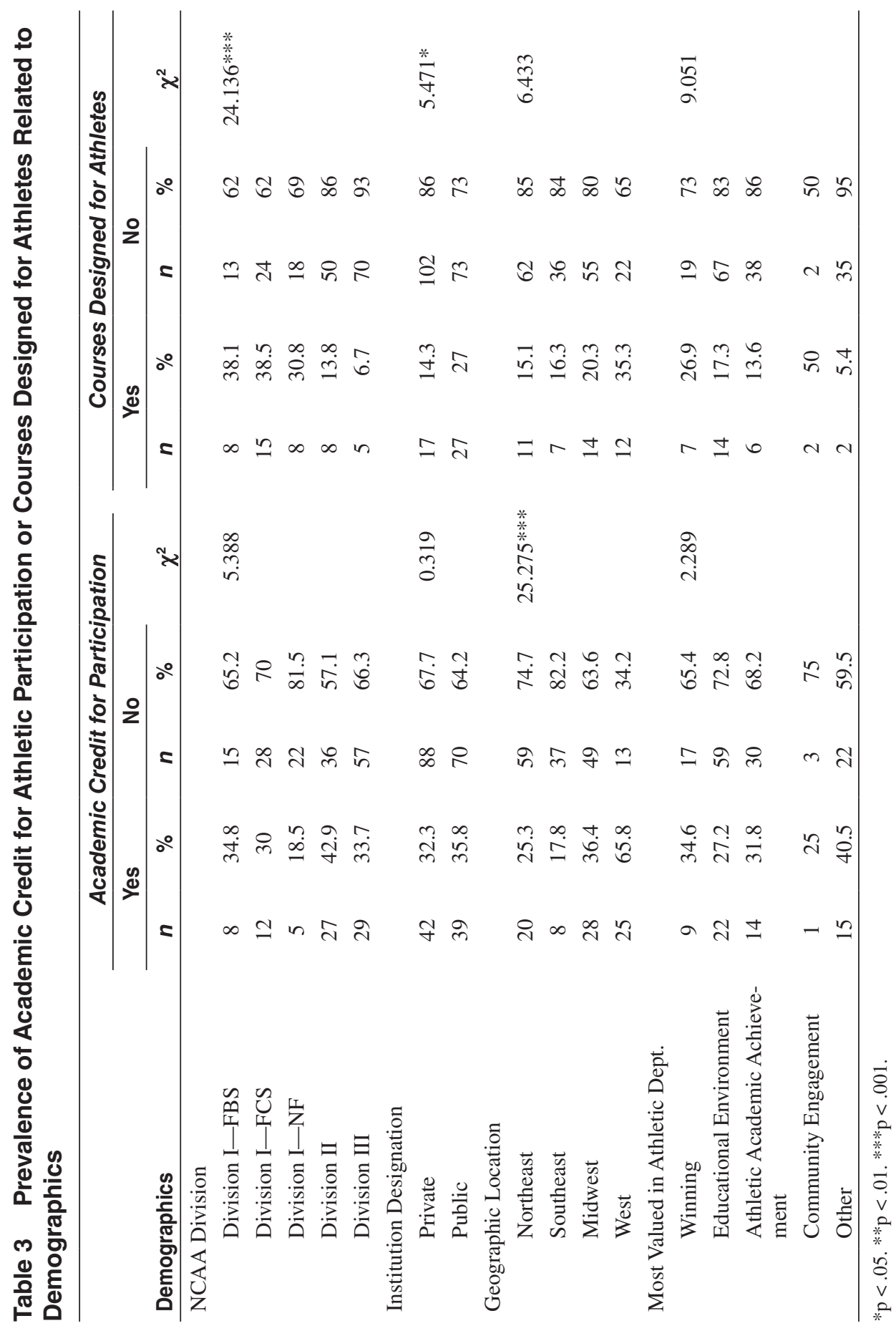


emerged between respondents' institutional affiliation and opinions about whether athlete-centric courses should be offered (see Table 4).

Examining first the perceptions of whether academic credit should be offered for participation in intercollegiate athletics, there were similar perceptions between NCAA divisions, geographic locations, and stated athletics department values. A significant difference, however, emerged between public and private institutions, with $59.1 \%$ of public institution respondents in favor of offering credit for participation, while only $41.4 \%$ of private institution representatives believed credit should be extended $\chi^{2}(1, n=205)=6.514, p<.05$.

Greater variance in perceptions emerged through analysis of whether respondents felt academic courses should be designed specifically for athletes. Though nonsignificant, $\chi^{2}(4, n=205)=7.122, p=.35$, a greater percentage of Division I respondents were in favor of courses designed for athletes than their Division III counterparts with the largest gap emerging between Division I-FCS advisors, $42.4 \%$ of whom felt courses should be designed for their athletes, and Division III advisors, $19.4 \%$ of whom indicated support for these types of courses. Significant differences again emerged between public and private institutions, $\chi^{2}(1, n=205)$ $=7.822, p<.005$, with public institutions more likely to support athlete-centric courses $(38 \%)$ than private institutions $(20.4 \%)$. Significant differences were also found in geographic location of respondents, $\chi^{2}(3, n=205)=13.503, p=.004$, with institutions in the west more likely to support athlete-centric courses $(48.5 \%)$ than those in the northeast (14.5\%).

\section{Content of Athlete-Centric Courses [RQ 2]}

The majority of athlete-specific courses offered by institutions $(68.1 \%, n=30)$ were based on life-skill topics, designed for freshmen to assist with a successful transition to college. Credit varied from one-half to six-credits for courses with titles including "success in academics and athletics," "effective learning," "life skills seminar," "summer bridge program," "academic learning strategies," and "university studies." Content in these courses includes time management skills, study skills, substance abuse, sexual health, mental health, nutritional habits, expectations of being an athlete, and life-balance. Of those that included details about these courses, $58 \%(n=14)$ mentioned the course was similar to others that all incoming freshman students take, but there is a special section for athletes. A smaller percentage $(20.8 \%, n=5)$ said the course is designed to help athletes who were below the typical standards of incoming students. One advisor remarked,

The course was established for students who were placed on academic probation after the first semester in college (cum GPA $<1.70$ ). This course was required for all probation level students. We, in the academic services for student-athletes unit, studied this course and looked at skills that were being taught and assessed that these skills should be refined before a student gets into academic difficulty. As a result, we petitioned the Provost office to allow us to pilot the course during the first semester of enrollment for incoming student-athletes (who chose to participate - not mandatory). In our opinion we surmised that academic skills are best retained before academic difficulty is met; takes the pressure off of having to score high grades in the semester on 


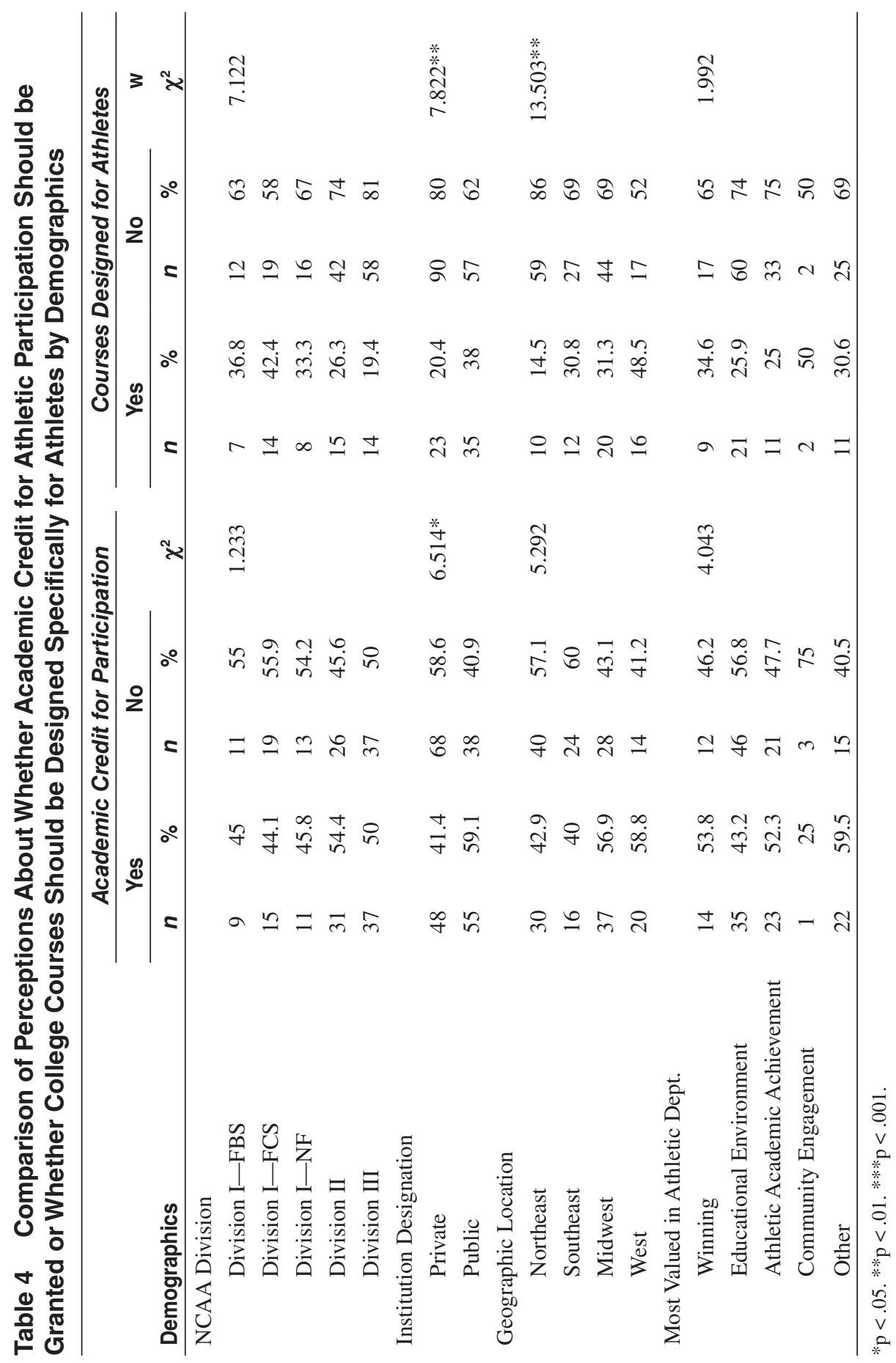


probation so that a student is not suspended after the second session. We have now been able to provide this course for the past four fall semesters (offering again this fall for the fifth semester) and those students who have taken the course either have graduated (in the first pilot course; transferred to another institution eligible; or will graduate within the next two to three semesters) (Respondent \#175, Division I-FCS).

The second most prominent category of courses offered $(27 \%, n=12)$ included two to three-credit leadership-based courses with titles such as "leads," "student leadership," and "personal and social responsibility." Only two courses (4.5\%) listed by the 44 institutions offering courses specifically for athletes did not fit in the life skills or leadership categories. These courses included "fitness for life for athletes," an academic health-centric course (one credit) and "educational psychology" (three credits).

In each of these instances, examples were provided of extensive cooperation and integration of campus units. One advisor shared,

"The Sports Management department in conjunction with the College of Human Ecology sought to establish a series of courses to prepare students for life after college. The initial idea was to develop a minor, which could be utilized by students to gain knowledge in areas such as health and wellness, financial literacy, and career planning. The class was established as an introduction to these topics, as well as campus resources. The class was advertised to student-athletes, but enrollment was open to any student" (Respondent \#11, Division I-FBS).

Similarly, one department "thought it would be a good idea to have a class that would orient student-athletes to the university, resources, and expectations as well as unify the student-athletes who play different sports... We pitched the idea to the Educational Psychology program on campus and they added the sections and pay our instructors" (Respondent \#228, Division I-FCS).

\section{Rationale Why Courses Should be Offered for Athletes [RQ 5]}

Of the $28.3 \%$ of respondents who felt courses should be designed and offered specifically for athletes, the rationale was dispersed among eight categories that emerged from narrative responses. The most common rationale mentioned by $32 \%$ of these respondents $(n=23)$ was the need for specialized training and support to discuss the unique challenges and opportunities they face. Somewhat related, the next most common rationale $(22 \%, n=16)$, was to provide a unique opportunity to review and apply lessons learned through athletics-courses that apply athletics interests in academic pursuits to facilitate deeper development of their sport, facilitate targeted critical thinking, and bridge the two worlds. Respondent examples in this category included courses such as sport psychology, sport conditioning, history of sport, sociology of sport, injury recovery, or nutrition. The third most common rationale $(15 \%, n=11)$ was specific to freshman athletes who, respondents mentioned, need a life-skills course to facilitate an optimal transition to college. The other five themes that emerged are listed in Table 5. 


\section{Table 5 Rationale to Support Why Courses Should Be Offered for} or Tailored Specifically to Athletes $(\mathrm{N}=73)$

\begin{tabular}{lcc}
\hline & $\%$ & $\boldsymbol{n}$ \\
\hline $\begin{array}{l}\text { To discuss unique challenges and opportunities they face } \\
\begin{array}{l}\text { To provide an opportunity to review and apply lessons learned } \\
\text { through athletics }\end{array}\end{array}$ & $32 \%$ & 23 \\
$\begin{array}{l}\text { Freshmen need a life-skills course to facilitate an optimal transi- } \\
\text { tion to college }\end{array}$ & $15 \%$ & 11 \\
$\begin{array}{l}\text { Credit should be given for activity classes only } \\
\begin{array}{l}\text { Special sections should be offered that do not conflict with prac- } \\
\text { tices schedules }\end{array}\end{array}$ & $12 \%$ & 9 \\
$\begin{array}{l}\text { Credit should be given for leadership training because there is } \\
\text { limited time }\end{array}$ & $4 \%$ & 3 \\
$\begin{array}{l}\text { Education that requires participation and assignments should } \\
\text { garner credit }\end{array}$ & $3 \%$ & 2 \\
Remedial education is needed & $3 \%$ & 2 \\
\hline
\end{tabular}

\section{Rationale Why Courses Should Not be Offered for Athletes [RQ 5]}

Of the $71.7 \%$ of respondents who felt courses should not be offered for or tailored specifically for athletes, the primary rationale for this belief expressed by $59 \%$ of the respondents $(n=64)$ included narratives expressing the belief that athletes should be integrated and experience college life like all other students. Others felt this type of course would be a special privilege that would limit opportunities when all courses should be open to the general student-body $(19 \%, n=21)$. Other less common responses included the belief that courses should not be offered specifically for athletes because it is against NCAA philosophy $(7 \%, n=8)$, athletics is not academic $(7 \%, n=8)$, it would be bad for the institutional image $(6 \%, n=6)$ and it is not an option for a small college $(1 \%, n=1)$.

\section{Discussion}

As leaders in higher education and government grapple with the best way to prepare productive citizens for the New World, an examination of holistic preparation for success in life after college is an essential element to this curricular formula (Walker, 2002). Reliant on a conceptual rationale of education through athletics, we have explored the prevalence and perceptions of for-credit educational opportunities designed for NCAA varsity athletes as an avenue of emergent curricular development that might be expanded for broader populations.

Despite the historically taboo nature of the education through athletics proposal (Brand, 2006; Colas, 2015; Feezell, 2015; Jenkins, 2011; Weight, 2015; Weight et al., 2015), 33.9\% of NCAA institutions within the sample currently provide credit for athletic participation, and over $20 \%$ have academic courses designed specifically 


\begin{tabular}{lcc}
$\begin{array}{l}\text { Table } 6 \quad \text { Rationale to Support Why Respondents Believe Courses } \\
\text { Should Not Be Offered for or Tailored Specifically to Athletes } \\
(\mathbf{N}=\mathbf{1 0 8})\end{array}$ & $\%$ & $\boldsymbol{n}$ \\
\hline & $59 \%$ & 64 \\
\hline $\begin{array}{l}\text { Athletes should be integrated and experience college life like all } \\
\text { others }\end{array}$ & $19 \%$ & 21 \\
Shouldn't offer special privileges or limit opportunities & $7 \%$ & 8 \\
Against NCAA philosophy / legislation & $7 \%$ & 8 \\
Athletics is not a major and not academic-it is extracurricular & $6 \%$ & 6 \\
Bad for institutional image to give athletes preferential treatment & $1 \%$ & 1 \\
\hline Not an option at a small college &
\end{tabular}

for athletes. The existence of these courses provides some evidence of the structural and philosophical academic integration of athletics within the traditional academy (Brand, 2006; Weight et al., 2015).

\section{Opportunities and Equity}

Most athlete-specific courses were related to strengthening life-skills and assisting freshmen with a successful college transition. Credits offered for these courses ranged from one-half to six credits. Given the NCAA legislation permitting the distribution of athletically-related financial aid to incoming students enrolling in summer programs before their initial year of eligibility (NCAA Bylaw 15.2.8.1.4), it can be surmised that at several institutions, athletes could be enrolled in up to six credits of athlete-only courses during their first semester in the summer or fall that may include mandatory "enrichment" training which generally includes academic screenings, academic workshops, policy and procedure training for drug testing, life skills seminars, and Title IX, sexual assault, substance abuse, and compliance education. At the same time, athletes at other institutions do not have this option. They would take a variety of for-credit courses available to any incoming student, and cover the mandatory NCAA training for no credit on top of their rigorous academic/athletic schedule. Decisions regarding curricula and credit allocation differ across institutions, but the dramatic variance raises concerns of equity and athlete workload (Benford, 2007; Hainline, 2015; Huml et al., 2014; Wolverton, 2014).

The next most common type of course offered among institutions were leadership-based programs. An example of this type of experience was facilitated at Drake University where leadership experts from across campus came together to develop curriculum with an experiential education requirement (Clubb, 2012). One such opportunity was undertaken by the football team in 2011 wherein the team traveled to Tanzania for a bowl game, built classrooms and orphanages with their on-field competitors from Mexico, climbed Mount Kilimanjaro, took an academic course taught by a member of the faculty titled "Leading with Emotional Intelligence," and shared their experiences in an event open to the public (Drake University Newsroom, 2011). 
These leadership courses require extensive cross-campus collaboration that can facilitate rich educational experiences. Faculty-student interaction is a strong predictor of academic success (Ortagus \& Merson, 2015), and the facilitation of faculty infusion into the athlete experience through academic-athletic interaction could address negative faculty perceptions of the athlete experience (e.g., Jolly, 2008; Lewinter, Weight, Osborne, \& Brunner, 2013). Interesting equity issues arise with these types of courses as well. Many athletics departments facilitate leadership-development seminars or extensive four-year programs that often require athlete attendance. Athletic-centric programming such as the Challenging Minds for Personal Success (CHAMPS)/Life Skills program (NCAA, 2007) or athletics leadership academies can certainly yield positive educational and social benefits for students similar to other intentionally designed campus organizations for nonathletes (Pascarella \& Terenzini, 2005), however, with some institutions infusing these programs into faculty-led for-credit curricula and others encouraging or requiring attendance on top of their regular academic and athletic commitment, it is concerning given the average weekly academic and athletic time commitments to be just under 80 hours per week (Hainline, 2015). These time constraints may dilute the potential for rich educational experiences and should be considered when weighing athlete-centric programming versus athlete-centric courses.

\section{Demographic Subgroup Variance}

Exploring the prevalence and perceptions of athlete-centric curricula between demographic subgroups, the most dramatic differences emerged between institutional geographic locations, with western schools considerably more likely to offer credit for athletics participation followed by institutions in the Midwest, Northeast, and Southeast, with $66 \%$ of western schools facilitating credit for participation compared with only $18 \%$ in the Southeast. This pattern, though less dramatic was mirrored in courses designed for athletes and perceptions about whether credit should be offered for participation or courses should be designed for athletes. Similarly, public schools were more likely to offer or support credit for participation and athlete centric courses in each measure. This consistent geographic pattern could signify a greater propensity for the western, generally newer, public institutions to adopt a more progressive adoption and acceptance of experiential learning through athletics, while perhaps faculties in the more historic private institutions tend to adopt traditionalist curricular attitudes calling for repair and restoration of previous educational methods (Walker, 2002).

Another significant finding emerged in the prevalence of courses designed for athletes, with Division I institutions significantly more likely to offer athlete-centric courses than their Division II or III counterparts. One reason for this finding was mentioned by Division III respondent 38: "As a small college, it would not be an option." The size of the student body in some Division II or III institutions make it impractical if not impossible to offer athlete-only sections of courses, or courses designed specifically for athletes with the average enrollment of 3,340 in Division III, and 6,015 at Division II schools, compared with the DI school average enrollment of 15,328 (Weight \& Zullo, 2015).

Alternative explanations for the greater number of athlete-centric courses in Division I schools can be gleaned from different lines of inquiry in the higher 
education literature. Both interpretations may explain why the majority of athletecentric courses were freshman or summer-bridge type courses. Approached from one lens, the prevalence of underprepared students being admitted to "big-time athletics" institutions in need of onboarding or summer bridge programs designed to help disadvantaged or first-generation college-bound students become more prepared for the rigors of college may justify the need for remedial athlete-education (Kezar, 2000; Smith \& Willingham, 2015). An alternative perspective, reliant on literature identifying the positive impact of summer bridge and onboarding courses, may posit that the institutions with greater financial resources are better-able to foster rich, focused academic experiences for their athlete demographic (McGlynn, 2012; Murphy, Gaughan, Hume \& Moore, 2010). Exploring the rationale for the curricular offerings can provide additional context for these findings.

\section{Rationale for Current Curricular Offerings}

In support of the education through athletics conceptual framework, a Division I FBS respondent mentioned, "the learning that takes place through athletics participation is simply an extension of the type of learning that occurs in a classroom environment. They take theories, philosophy and research and apply it in a stressful and intense environment that produces measurable results" (Respondent 12). Division II respondent 59 echoed, "We are teachers within our department and team. We want to develop the best all-around people, body and mind, and athletic participation serves that purpose. By bridging these lessons with classroom application, we can richly accomplish that goal." Three of the emergent themes encapsulated fundamental elements of the education through athletics hypothesis: the courses "provide a unique opportunity to review and apply lessons learned through athletics," "facilitate deeper development of their sport and facilitate targeted critical thinking which can bridge their two worlds," and elicit "specialized training and support to discuss unique challenges and opportunities they face." These types of courses support literature documenting the unique educational opportunities and outcomes that participation in athletics can foster (Center for Learning Outcomes Assessment, 2010; Henderson et al., 2006; Long \& Caudill, 1991; Ryan, 1989; Weight et al., 2014; Weight et al., 2015; Williams, 2013).

Several of the other themes did not reflect an education through athletics intent, including those emphasizing the need for special sections of courses not conflicting with practice schedules, or those that facilitate remedial education for athletes who do not meet the academic profile of regular admits. These themes support literature documenting the athlete-student experience wherein participation in athletics is negatively associated with satisfaction and involvement in college because the athletes are set up to fail or are exploited (Fountain \& Finley, 2011; Lanter \& Hawkins, 2013; Smith \& Willingham, 2015).

Given the dominance of onboarding life skills courses with $70 \%$ of the courses designed for athletes holding similar titles and purposes, it would seem only a very small amount of these courses were designed to infuse a true bridge between the athletic experiences and the academy. One such effort was explained by a division II respondent, "We have spent the last two years creating an academically-grounded leadership studies curriculum in order to enhance the athletic experience and career preparation for all student-athletes" (Respondent 6). This person also passionately 
mentioned, "Athletics participation is a unique field laboratory in which leadership lessons are practiced daily. To not create classes in which those lessons can be reviewed, evaluated and enhanced is negligence" (Division II Respondent 6). This encapsulation of the unique laboratory of learning documented in athletics (Astin, 1993; Center for Learning Outcomes Assessment, 2010; Chalfin et al., 2015; Gaston-Gayles \& Hu, 2009; Henderson et al., 2006; Long \& Caudill, 1991; Ryan, 1989; Shulman \& Bowen, 2001; Umbach et al., 2006; Weight et al., 2014; Williams, 2013), and the need for leadership development (Walker, 2002) lends weight toward the question why more institutions are not embracing this practice as there seems to be tremendous untapped potential for rich educational opportunities.

\section{Limitations and Future Research}

This research provides a baseline of current practices and insights relative to the realm of athlete-centric courses in NCAA intercollegiate athletics, and facilitates a point from which to launch more specific inquiry and theory development in this fertile field of education through athletics. The population of interest in this study was NCAA athletic academic advisors, and the sample was representative of the population in all demographic categories measured other than race with a $14 \%$ overrepresentation of white respondents. Future studies of this population should take additional measures to seek a truly representative sample. Future research should also expand the populations of interest as athletic academic advisors represent a very unique and limited subset within the University community. A future study examining the perceptions of athletes or faculty relative to athlete-centric courses or courses for all students centered on elite performance theoretically or in practice would be especially beneficial for advancing this line of research. Institutional policy could also be examined relative to the development of athlete-centric courses. The impact of school policy on advisor perceptions or the existence of physical education requirements on the feasibility of offering credit for athletic participation would be interesting to investigate in future studies. Another area of inquiry could examine whether athletics-related majors with targeted educational opportunities foundational to specific careers should be created, to prepare athletes choosing to "go pro" or become college coaches.

This study was exploratory in nature and reliant on descriptive statistics, Chisquare analysis, and a small number of open-ended qualitative responses. While appropriate sampling methods were used and the sample was representative of the population, there may be sampling error that affects the generalizability of the results. The authors did not examine any impact, whether short or long-term, of taking these courses on institutional indicators (e.g., Athletic Progress Rating (APR)) or athlete academic experience (e.g., persistence and retention, GPA, or major selection). A future study could examine whether there are statistical differences in institutional indicators or athlete academic experience measures between institutions offering these courses and those that do not. Lastly, schools not possessing academic support services within their athletic department were excluded from the sample population. A future study could examine the perceptions of administrators of those institutions, as they likely have academic-related responsibilities with their student-athletes. 


\section{Implications and Recommendations}

The findings in this study document tremendous disparity in institutional offerings and perspectives. With the increasing oversight and regulation in the NCAA, the list of mandated and recommended trainings have skyrocketed encroaching further and further into the athlete's time (Benford, 2007; Hainline, 2015; Huml et al., 2014; Wolverton, 2014). The attitudes, intentions, and structures of some schools over others offer an interesting insight into how disparate the athlete experiences can be depending on how the schools incorporate the educational requirements requisite to being an NCAA athlete. One respondent from a school with a 6-credit hour onboarding course mentioned, "this course is pretty much offered at every other Division I institution to help students transition into college life and specifically address the expectations of being a student-athlete" (Division I-FCS Respondent 82). Several others echoed the courses provide an academic forum to discuss many of the NCAA leadership training mandates that are fundamental to success of all students, but particularly important to athletes. Interestingly, others thought offering this type of course was against NCAA rules, and would be seen as a "jock class" bad for the institutional image (Smith \& Willingham, 2015). Hundreds of training-hours in some institutions are embedded into the academic experience and integrated into the university, while others are done independent of for-credit academic structures, adding additional commitments to the athletes who already have academic and athletic time commitments averaging just under 80 hours per week (Benford, 2007; Hainline, 2015; Huml, Svensson, \& Hancock, 2014; Wolverton, 2014).

An interesting case study could be drawn from the experiences of athletes at the University of North Carolina, a southeastern school that has drawn tremendous attention for a "paper-class" scandal affecting over 3,100 students of which 47\% were athletes enrolled over nearly two decades in courses overseen and graded by an administrator in the Department of African and Afro-American Studies (Smith \& Willingham, 2015; Wainstein, Jay, \& Kukowski, 2014). This is an institution that offered no credit for athletic participation and no athlete-centric courses (on par with the regional findings in this study), yet it has one of the leading and most robust 4-year leadership academies for athletes in the nation (Weight, 2015). This four-year program facilitates hundreds of hours of academic leadership training on top of the NCAA training mandates and life-skills seminars. These no-credit educational experiences at some peer institutions would equate to a minimum of 18 credit hours if formalized into curricula. This illustration of the stark variance in institutional philosophy regarding education through athletics raises important issues of equity, and possible consequences for institutions that do not facilitate educational opportunities, where time-sapped athletes and sympathetic staffers might strive to find the path of least resistance to survival of the daunting realities of demanding universities, demanding coaches, passion for athletics, and NCAA eligibility requirements.

\section{Implications for Higher Education Professionals}

This study documents tremendous inequity in interinstitutional practices of facilitating academic courses for athletes. This variance in institutional procedure can result 
in significant fluctuations in athlete time, competitive advantages, and opportunities for education through athletics. Given the extensive policies the NCAA regulates to facilitate an even playing field, this dramatic divide in interinstitutional procedure presents an interesting challenge that warrants further inquiry.

The majority of respondents did not support athlete-centric courses, which is on-par with historical practices and prejudices (Brand, 2006). As the politicaleducational arena grapples with unprecedented scrutiny, faculties and administrators should focus their efforts on facilitating rich holistic educational opportunities and experiences. The athlete-educational experience that has been a concern since the inception of intercollegiate athletics has led many faculties to fear athlete-centric programming for reasons including an exacerbation of social isolation or the perceived nonacademic collective hubris and entitlement of athletes.

Although there is a degree of isolation within every academic discipline with major-only courses and experiences that do not require justification, the unique nature of the athlete experience may necessitate additional consideration due to the social, commercial, and administrative pressures that could lead to academic clustering and athlete-segregation. Social isolation is a major contributing factor to athletic role-engulfment, academic disengagement, and institutional detachment (Adler \& Adler, 1991) and should be a concern when conceptualizing exclusive access for courses. For this reason, a practical approach to athlete-centric educational experiences should be conscious of these realities and address concerns judiciously through credit limitations, cross-disciplinary faculty involvement, and the inclusion of nonathlete elite performers in the programming.

Along this vein, a concrete approach to facilitating equitable educational opportunities might include three distinct elements. First, a 3-credit "onboarding" course specific for athletes to institutionalize many of the first-semester mandatory NCAA trainings in addition to life-skills initiatives which may be similar to other first-semester courses offered to the general student-body. Ideally, the course would connect a broad array of cross-disciplinary faculty and campus support units to participate on a rotating basis to expose the new students to educational opportunities throughout campus, while bringing faculty into athletics discussions and informing them of NCAA regulations. Depending on the content of this course, it could include all incoming students to address the possibility of athlete-isolation, however, special break-out sessions to allow adequate discussion of specific NCAA material may necessitate some degree of athlete centricity.

A second possibility would include offering credit for participation but infusing the traditional athlete-participation experience with educational elements. For instance, perhaps in a school with a physical education requirement, faculty that might normally teach a strength training course could supplement strength training practices the athletes are already required to do with lectures on physiology, nutrition, or training principles. This could be incorporated into campus physical education requirements, but special 1 or 3 -credit sections (dependent on existing campus structures) could be taught to build upon the unique training varsity and possibly elite recreational or club-sport athletes already receive. The allocation of credit and academic structure of these participationcentric courses should match institutional academic philosophy, though norms should be recommended to facilitate competitive parity. A series of four 1-credit courses over four years, or a 3-credit course and additional 1-credit course over 
two years integrated within the physical education, nutrition, health, kinesiology, exercise and sport science, or physiology department are two possibilities that emerged.

A final educational possibility would be a field of study related to elite performance. This could include varsity athletes, musicians, orators, dancers, thespians, etc. This major or minor could infuse the elite performance experiences students are having with material designed to build upon those experiences. Courses might include performance psychology, leadership and group dynamics, performance nutrition, media training, entrepreneurship, etc. in addition to two 3-credit "field experience" opportunities that allow the students to reflect upon their elite experiences, apply literature to their (on-the-court) study, meet with a faculty and field supervisor (coach) to set and track learning goals, and infuse institutionalized scholarship and educational legitimacy into their traditionally "extracurricular" endeavor. Perhaps as the body of literature centered on the educational outcomes of intercollegiate athletics participation grows, we will embrace the unique laboratory of learning possible through NCAA competition and commercial opportunities, integrate faculty and coaches to bridge theory and practice on the field, on camera, in the training room, and in the classroom, and reverse the centuries of bias that view athletics as an auxiliary to the university (Brand, 2006; Feezell, 2015; Sack, 2009; Weight et al., 2015).

\section{References}

Adeniji, A. (2015, Oct 21). Money well spent? A \$50 million gift to nurture student-athlete leaders. Inside Philanthropy. Retrieved from http://www.insidephilanthropy.com/ home/2015/10/21/money-well-spent-a-50-million-gift-to-nurture-student-athlet.html

Anderson, M.D. (2012). The leader development of college students who participate in different levels of sport (Doctoral dissertation, The Ohio State University).

Adler, P.A., \& Adler, P. (1991). Backboards and blackboards: College athletes and role engulfment. Columbia University Press.

Astin, A.W. (1993). What matters in college? Four critical years revisited. San Francisco, CA: Jossey-Bass.

Benford, R.D. (2007). The college sports reform movement: Reframing the "edutainment" industry. The Sociological Quarterly, 48, 1-28. doi:10.1111/j.1533-8525.2007.00068.x

Benson, K. (2000). Constructing academic inadequacy: African American athletes' stories of schooling. The Journal of Higher Education, 71, 223-246. doi:10.2307/2649249

Beyer, J.M., \& Hannah, D.R. (2000). The cultural significance of athletics in US higher education. Journal of Sport Management, 14, 105-132. doi:10.1123/jsm.14.2.105

Bok, D. (2009). Universities in the marketplace: The commercialization of higher education. Princeton, NJ: Princeton University Press. doi:10.1515/9781400825493

Bowen, W. G., \& Levin, S. A. (2003). Reclaiming the game: College sports educational values.

Princeton, NJ: Princeton University Press.

Brand, M. (2006). The role and value of intercollegiate athletics in universities. Journal of the Philosophy of Sport, 33, 9-20. doi:10.1080/00948705.2006.9714687

Capranica, L., \& Millard-Stafford, M.L. (2011). Youth sport specialization: how to manage competition and training. International Journal of Sports Physiology and Performance, 6(4), 572-579. PubMed doi:10.1123/ijspp.6.4.572

Center for Learning Outcomes Assessment, Inc. (2010). Growth, Learning, and Development of Intercollegiate Student-Athletes. Retrieved from: http://uniloa.com/reports.pdf 
Chaddock, L., Neider, M.B., Voss, M.W., Gaspar, J.G., \& Kramer, A.F. (2011). Do athletes excel at everyday tasks? Medicine and Science in Sports and Exercise, 43(10), 1920-1926. PubMed

Chalfin, P., Weight, E., Osborne, B., \& Johnson, S. (2015). The value of intercollegiate athletics participation from the perspective of employers who target athletes. Journal of Issues in Intercollegiate Athletics, 8, 1-27.

Checkoway, B. (2001). Renewing the civic mission of the American research university. The Journal of Higher Education, 72(2), 125-147. doi:10.2307/2649319

Chickering, A.W., \& Reisser, L. (1993). Education and Identity. San Francisco, CA: Jossey-Bass.

Clubb, S.H. (2012). Beyond carrots and sticks: Toward a transformative model of division I athletics. Liberal Education, 98(4), 42-47.

Colas, Y. (2015, April 10). Why we should have a sports studies major. Between the Lines. Retrieved from: http://yagocolas.com/2015/04/10/

Comeaux, E., \& Harrison, C.K. (2007). Faculty and male student-athletes: Racial differences in the environmental predictors of academic achievement. Race, Ethnicity and Education, 10, 199-214. doi:10.1080/13613320701330726

Cooper, C.G., Weight, E.A., \& Pierce, D. (2014). The leader-value continuum: NCAA Division I core values and transformational leadership. International Journal of Sport Management, 15(2), 151-171.

Cooper, J.N., \& Hawkins, B. (2014). The transfer effect: A critical race theory examination of Black male transfer student athletes' experiences. Journal of Intercollegiate Sport, 7, 80-104. doi:10.1123/jis.2013-0033

Corack, G.J. (2014). The Relationship of Collegiate Athletic and Recreational Sports Involvement to Student Success and Persistence. (Doctoral dissertation. Eastern Kentucky University).

Creswell, J.W. (2012). Educational research: Planning, conducting, and evaluating quantitative and qualitative research (4th ed.). Boston, MA: Pearson Education.

Creswell, J. W. (2013). Research design: Qualitative, quantitative, and mixed methods approaches. Sage publications.

Cullingford, C., \& Blewitt, J. (Eds.). (2013). The sustainability curriculum: The challenge for higher education. New York, NY: Routledge.

Desrochers, D. (2013). Academic spending versus athletic spending: Who wins? Washington, DC: American Institutes for Research.

DeVellis, R.F. (2012). Scale development: Theory and applications (3rd ed.). Thousand Oaks, CA: Sage Publications.

Drake University Newsroom. (2011, August 25). Drake University football players to present Tanzania trip experiences. Retrieved from: http://news.drake.edu/2011/08/25/

Donnor, J.K. (2005). Towards an interest-convergence in the education of African-American football student-athletes in major college sports. Race, Ethnicity and Education, 8, 45-67. doi:10.1080/1361332052000340999

Eckard, E.W. (2010). NCAA athlete graduation rates: Less than meets the eye. Journal of Sport Management, 24, 45-58. doi:10.1123/jsm.24.1.45

Feezell, T. (2015). Educated ignorance: what faculty don't know and why faculty can't lead intercollegiate athletics reform. Journal of Amateur Sport, 1(1), 81-100. doi:10.17161/ jas.v1i1.4925

Fountain, J. J., \& Finley, P. S. (2009). Academic majors of upperclassmen football players in the Atlantic Coast Conference: An analysis of academic clustering comparing white and minority players. Journal of Issues in Intercollegiate Athletics, 2, 1-13.

Fountain, J.J., \& Finley, P.S. (2011). Academic clustering: A longitudinal analysis of a Division I football program. Journal of Issues in Intercollegiate Athletics, 4, $24-41$.

Gaston-Gayles, J., \& Hu, S. (2009). The influence of student engagement and sport participation on college outcomes among Division I student athletes. The Journal of Higher Education, 80(3), 315-333. doi:10.1353/jhe.0.0051 
Gerdy, J.R. (2006). Air ball: American education's failed experiment with elite athletics. Jackson, MS: University Press of Mississippi.

Gill, M. (2015). Value and contribution of the participation in intercollegiate athletics on the personal development of community college-aged students (Doctoral dissertation. University of Nebraska-Lincoln).

Glatthorn, A., \& Jailall, J. (2000). "Curriculum for the new millennium" in Brandt, R. (ed.). Education in a new era: ASCD Yearbook. Alexandria, VA: ASCD.

Gould, D., \& Carson, S. (2008). Life skills development through sport: Current status and future directions. International Review of Sport and Exercise Psychology, 1(1), 58-78. doi:10.1080/17509840701834573

Hainline, B. (2015, April 8). Personal and institutional search for trust in sport. The Department of Exercise and Sport Science's Blythe Lecture, Chapel Hill, NC.

Hardcastle, S.J., Tye, M., Glassey, R., \& Hagger, M.S. (2015). Exploring the perceived effectiveness of a life skills development program for high-performance athletes. Psychology of Sport and Exercise, 16, 139-149. doi:10.1016/j.psychsport.2014.10.005

Hardin, R., \& Pate, J.R. (2013). Playbook vs. textbook: Examining academic transitioning of NCAA Division I-FBS football student-athletes. Journal for the Study of Sports and Athletes in Education, 7, 229-244. doi:10.1179/1935739713Z.00000000014

Hayes, A.F., \& Krippendorff, K. (2007). Answering the call for a standard reliability measure for coding data. Communication Methods and Measures, 1(1), 77-89. doi:10.1080/19312450709336664

Hellison, D.R. (2003). Teaching responsibility through physical activity (2nd ed.). Champaign, IL: Human Kinetics.

Henderson, D.J., Olbrecht, A., \& Polachek, S.W. (2006). Do former college athletes earn more at work? A nonparametric assessment. The Journal of Human Resources, 41(3), 558-577. doi:10.3368/jhr.XLI.3.558

Hong, F. (2004). Innocence lost: child athletes in China. Sport in Society, 7(3), 338-354. doi:10.1080/1743043042000291677

Hopkins, K.D. (1998). Educational and psychological measurement and evaluation. Needham Heights, MA: Allyn \& Bacon.

Hughes, T. (1968, first published, 1857). Tom Brown's school days. New York, NY: Airmont Publishing Company.

Huml, M.R., Hancock, M.G., \& Bergman, M.J. (2014). Additional support or extravagant cost? Student-athletes' perceptions on athletic academic centers. Journal of Issues in Intercollegiate Athletics, 7, 410-430.

Huml, M.R., Svensson, P.G., \& Hancock, M.G. (2014). Exploring the role of educational institutions in student-athlete community engagement. Journal of Issues in Intercollegiate Athletics, 7, 224-244.

Ingrassia, B.M. (2012). The rise of gridiron university: Higher education's uneasy alliance with big-time football. Lawrence, KS: University Press of Kansas.

Irick, E. (2015). NCAA race and gender demographics, 1995-2014. National Collegiate Athletics Association. Retrieved from http://web1.ncaa.org/rgd

Jenkins, S. (2011, October 5). NCAA colleges should consider offering sports as an academic major. The Washington Post. Retrieved from: http://www.washingtonpost.com/ sports/2011/10/05/gIQAF6ijOL_story.html

Jolly, C.J. (2008). Raising the question \#9 Is the student-athlete population unique? And why should we care? Communication Education, 57(1), 145-151. doi:10.1080/ 03634520701613676

Kezar, A. (2000). Summer Bridge Programs: Supporting All Students. ERIC Digest.

Lang, M. (2010). Intensive training in youth sport: A new abuse of power? In K.K.P. Vanhoutte

Fairbairn, G., \& Lang, M. (Eds.), Bullying and the Abuse of Power. Oxford, UK: Interdisciplinary Press. (pp. 57-64). 
Lanter, J.R., \& Hawkins, B.J. (2013). The economic model of intercollegiate athletics and its effects on the college athlete educational experience. Journal of Intercollegiate Sport, 6(1), 86-95. doi:10.1123/jis.6.1.86

Lawrence, S.M., Harrison, C.K., \& Stone, J. (2009). A day in the life of a male college athlete: A public perception and qualitative campus investigation. Journal of Sport Management, 23, 591-614. doi:10.1123/jsm.23.5.591

Lewinter, G., Weight, E.A., Osborne, B., \& Brunner, J. (2013). A polarizing issue: Faculty and staff perceptions of intercollegiate athletic academics, governance, and finance postNCAA investigation. Journal of Applied Sport Management, 5(4), 73-100.

Long, J.E., \& Caudill, S.B. (1991). The impact of participation in intercollegiate athletics on income and graduation. The Review of Economics and Statistics, 525-531. doi: $10.2307 / 2109580$

Malina, R.M. (2010). Early sport specialization: roots, effectiveness, risks. Current Sports Medicine Reports, 9(6), 364-371. PubMed doi:10.1249/JSR.0b013e3181fe3166

Marsh, C.J. (2009). Key concepts for understanding curriculum. New York, NY: Routledge.

McCann, Z. (2012, March 1). Athletes more prepared for real world? ESPN.com. Retrieved from http://espn.go.com/espn/page2/story/_id/7633078/

McCormick, R.A., \& McCormick, A.C. (2006). The myth of the student-athlete: The college athlete as employee. Washington Law Review (Seattle, Wash.), 81, 71-157.

McGlynn, A.P. (2012). Do summer bridge programs improve first-year success? The Hispanic Outlook in Higher Education, 22(19), 11-12.

Mingle, J.R. (2000). Higher education's future in "corporatized" economy (Occasional Paper No. 44). Washington, DC: Association of Governing Boards of Universities and Colleges.

Murdoch, E.B. (1990). Physical education and sport: The interface. In N. Armstrong (Ed.), New Directions in physical education (Vol. 1, pp. 63-78). Champaign, IL: Human Kinetics.

Murphy, T.E., Gaughan, M., Hume, R., \& Moore, S.G. (2010). College graduation rates for minority students in a selective technical university: will participation in a summer bridge program contribute to success? Educational Evaluation and Policy Analysis, 32(1), 70-83. PubMed doi:10.3102/0162373709360064

National Collegiate Athletic Association. (n.d.). Graduation Rates. from http://www.ncaa. org/sites/default/files/DIGradRateReport08.pdf

National Collegiate Athletic Association. (2007). NCAA CHAMPS/Life Skills Program. Retrieved from http://www.ncaa- publications.com/productdownloads/LS07.pdf

National Collegiate Athletics Association. (2014). Composition and sport sponsorship of the NCAA membership. Retrieved from http://www.ncaa.org/about/who-we-are/membership/composition-and-sport-sponsorship-ncaa-membership.

National Collegiate Athletics Association. (2015). Division I Manual. Indianapolis, IN: NCAA Publications.

Nulty, D.D. (2008). The adequacy of response rates to online and paper surveys: what can be done? Assessment \& Evaluation in Higher Education, 33(3), 301-314. doi:10.1080/02602930701293231

Oriard, M. (2001). King football: Sport \& spectacle in the golden age of radio \& newsreels, movies \& magazines, the weekly \& daily presses. Chapel Hill, NC: The University of North Carolina Press.

Oriard, M. (2012). NCAA academic reform: History, context and challenges. Journal of Intercollegiate Sport, 5(1), 4-18. doi:10.1123/jis.5.1.4

Ortagus, J.C., \& Merson, D. (2015). Leveling the Playing Field: Faculty Influence on the Academic Success of Low-Income, First-Generation Student-Athletes. Journal for the Study of Sports and Athletes in Education, 9(1), 29-49. doi:10.1179/19357397 15Z.00000000034

Pargman, D. (2012, November 26). End the charade: Let athletes major in sports. The Chronicle of Higher Education. Retrieved from http://chronicle.com/article/135894/ 
Pascarella, E. T., \& Terenzini, P. T. (2005). How college affects students: A third decade of research. San Francisco, CA: Jossey-Bass.

Park, R.J. (2007). "Embodied Selves": The rise and development of concern for physical education, active games and recreation for American women, 1776-1865. The International Journal of the History of Sport, 24(12), 1508-1542. doi:10.1080/09523360701618933

Paule-Koba, A.L., \& Farr, N.E. (2013). Examining the experiences of former DI and D-III nonrevenue athletes. Journal of Issues in Intercollegiate Athletics, 6, 194-215.

Pascarella, E.T., \& Smart, J.C. (1991). Impact of intercollegiate athletic participation for African American and Caucasian men: Some further evidence. Journal of College Student Development, 32, 123-130.

Pascarella, E.T., Truckenmiller, R., Nora, A., Terenzini, P.T., Edison, M., \& Hagedorn, L.S. (1999). Cognitive impacts of intercollegiate athletic participation: Some further evidence. The Journal of Higher Education, 70, 1-26. doi:10.2307/2649116

Plunkett, M.R., Weight, E.A., Osborne, B., \& Lancaster, E. (2016). The value of intercollegiate athletics participation from the perspective of former ACC athletes. International Journal of Sport Management, 17(1), 1-21.

Putney, C. (2009). Muscular Christianity: Manhood and sports in protestant America, 1880-1920. Cambridge, MA: Harvard University Press.

Rader, B.G. (1999). American sports: From the age of folk games to the age of televised sports (4th ed.). Englewood Cliffs, NJ: Prentice-Hall.

Rosche, M. (2013). Former K-State athlete discuss why student-athletes make great employees. Retrieved from https://www.careerathletes.com/news_detail.php?id=18

Ross, S.F. (2012). Radical reform of intercollegiate athletics: Antitrust and public policy implications. Tulane Law Review, 86, 933-1397.

Ryan, F. J. (1989). Participation in intercollegiate athletics: Affective outcomes. Journal of College Student Development. 30(2): 122-128.

Sack, A.L. (2009). Clashing models of commercial sport in higher education: Implications for reform and scholarly research. Journal of Issues in Intercollegiate Athletics, 2, 76-92.

Sack, A.L., \& Staurowsky, E.J. (1998). College athletes for hire: The evolution and legacy of the NCAA's amateur myth. Westport, CT: Praeger Publishers.

Saldaña, J. (2009). The coding manual for qualitative researchers. Los Angeles, CA: Sage.

Shulman, J.L., \& Bowen, W.G. (2001). The game of life: College sports and educational values. Princeton, NJ: Princeton University Press.

Slaughter, S., \& Rhoades, G. (2004). Academic capitalism and the new economy: Markets, state, and higher education. Baltimore, MD: Johns Hopkins University Press.

Smith, J.M., \& Willingham, M. (2015). Cheated: The UNC scandal, the education of athletes, and the future of big-time college sports. Lincoln, NE: University of Nebraska Press.

Smith, R. (2011). Pay for play: A history of big-time college athletic reform. Urbana, Illinois: University of Illinois Press.

Soshnick, S. (2013, October 16). Wall Street hires losers turned winners after college athletics. Bloomberg. Retrieved from http://www.bloomberg.com/news/2013-10-16/ wall-street-hires-losers-turned-winners-after-college-athletics.html

Southall, R.M., \& Staurowsky, E.J. (2013). Cheering on the collegiate model: Creating, disseminating, and imbedding the NCAA's redefinition of amateurism. Journal of Sport and Social Issues, 37, 403-429. doi:10.1177/0193723513498606

Strauss, A., \& Corbin, J. (1998). Basics of qualitative research: Techniques and procedures for developing grounded theory (2nd ed.). Thousand Oaks, CA: Sage.

Thelin, J.R. (1994). Games colleges play: Scandal and reform in intercollegiate athletics. Baltimore, MD: Johns Hopkins University Press.

Umbach, P.D., Palmer, M.M., Kuh, G.D., \& Hannah, S.J. (2006). Intercollegiate athletes and effective educational practices: Winning combination or losing effort? Research in Higher Education, 47(6), 709-733. doi:10.1007/s11162-006-9012-9 
University Learning Outcomes Assessment. (2011). Intercollegiate athletes report of means. Retrieved from http://www.measuringbehaviors.com/AthletesFinal2011.pdf.

Van Rheenen, D. (2011). Exploitation in the American academy: College athletes and self- perceptions of value. The International Journal of Sport and Society, 2, 11-26. doi:10.18848/2152-7857/CGP/v02i04/53882

Van Rheenen, D. (2013). Exploitation in college sports: Race, revenue, and educational reward. International Review for the Sociology of Sport, 48(5), 550-571. doi:10.1177/1012690212450218

Walker, D.F. (2002). Fundamentals of curriculum: Passion and professionalism. New York, NY: Routledge.

Wainstein, K.L., Jay, A.J., III, \& Kukowski, C.D. (2014). Investigation of irregular classes in the department of African and Afro-American Studies at the University of North Carolina at Chapel Hill. New York, NY.

Weight, E.A. (2015, March 23). Time to embrace the art and science of college sports. The Chronicle of Higher Education. Retrieved from: http://chronicle.com/article/228665/

Weight, E.A., Cooper, C.G., \& Popp, N. (2015). The coach-educator: NCAA Division I coach perspectives about an integrated organizational structure. Journal of Sport Management, 29(5). doi:10.1123/jsm.2014-0006

Weight, E.A., Navarro, K., Huffman, L., \& Smith-Ryan, A. (2014). Quantifying the psychological benefits of intercollegiate athletics participation. Journal of Issues in Intercollegiate Athletics., 7, 390-409.

Weight, E.A., \& Zullo, R.H. (2015). Administration of intercollegiate athletics. Champaign, IL: Human Kinetics.

Williams, D. (2013, October 2). Why you should fill your company with 'athletes'. Forbes. Retrieved from http://www.forbes.com/sites/davidkwilliams/2013/10/02/why-youshould-fill-your-company-with-athletes/

Wolverton, B. (2014, December 11). Payments for athletes? Check. Players with balanced lives? Not so much. The Chronicle of Higher Education. Retrieved from http://chronicle. com/article/Payments-for-Athletes-Check/150807/

Zimbalist, A. (1999). Unpaid professionals: Commercialism and conflict in big-time college sports. Princeton, NJ: Princeton University Press. 